\title{
Potensi Tumbuhan Lokal Di Areal Tembawang Desa Suka Jaya Kabupaten Sintang
}

\author{
Ria Rosdiana Hutagaol \\ Fakultas Pertanian Universitas Kapuas Sintang \\ Email : riarose.h@gmail.com
}

\begin{abstract}
Abstrak: Tembawang merupakan bentuk agroforestri khas Kalimantan Barat, yang juga diterapkan oleh masayarakat Suku Dayak di Desa Suka Jaya Kecamatan Tempunak Kabupaten Sintang, Kalimantan Barat. Penelitian ini bertujuan untuk mengetahui tumbuhan lokal yang terdapat di areal tembawang Desa Suka Jaya. Penelitian dilakukan dengan menggunakan teknik wawancara untuk mendapatkan informasi mengetahui jenis-jenis tumbuhan lokal serta teknik eksplorasi lapangan untuk mengetahui jenis-jenis tumbuhan lokal yang mencakup nama lokal dan nama ilmiah, famili, habitus serta kelompok tumbuhan. Berdasarkan hasil penelitian, Tembawang Desa Suka Jaya memiliki 12 jenis tumbuhan lokal dan 10 famili yang merupakan kelompok tumbuhan penghasil buah, tumbuhan obat dan tumbuhan hias. Tumbuhan penghasil buah mendominasi areal Tembawang Desa Suka Jaya yaitu 7 jenis dengan habitus berupa pohon, diikuti kelompok tumbuhan obat sebanyak 3 jenis dan kelompok tumbuhan hias sebanyak 2 jenis.
\end{abstract}

Kata Kunci : Desa Suka Jaya, Tembawang, Tumbuhan Lokal

\section{PENDAHULUAN}

Indonesia merupakan negara mega biodiversitas yang kaya akan potensi tumbuhan lokal. Tumbuhan lokal didefinisikan sebagai sumberdaya alam hayati berupa tumbuhan yang terdapat di daerah tertentu dan dapat dimanfaatkan sebagai bahan pangan dan sumber belajar (Wibowo, 2012: 41) Dalam penelitian ini tumbuhan lokal adalalah semua tumbuhan yang tumbuh secara alami di areal hutan yang dikenal dengan istilah Tembawang, yang termasuk kedalam tumbuhan penghasil buah, tumbuhan obat serta tumbuhan hias.

Tembawang merupakan salah satu bentuk agroforestri atau wanatani yang biasa dilakukan oleh masyarakat dari Suku Dayak di Kalimantan, termasuk Suku Dayak di Desa Suka Jaya Kecamatan Tempunak Kabupaten Sintang, Kalimantan Barat. Agroforestri merupakan bentuk pengelolaan lahan terpadu untuk meningkatkan produktivitas lahan baik secara ekologis maupun ekonomis, yang banyak diterapkan oleh masyarakat 
di Kalimantan Barat, dimana hasil dari lahan tersebut pada umumnya untuk dikonsumsi sendiri. Menurut MU. Putra et al (2020), Potensi Agroforestri dapat dilihat dari dua aspek, yaitu potensi vegetasi penyusun agroforestri dan potensi ekonomi komoditi agroforestri. untuk potensi vegetasi penyusun agroforesti dengan melihat hasil hutan kayu dan hasil hutan non kayu, sedangkan potensi ekonomi dilihat dari nilai ekonomi dari produk agroforestri yang dihasilkan dari sistem agroforestri yang ada.

Tembawang merupakan salah satu bentuk agroforestri khas masyarakat di Kalimantan Barat. De Jong et al. (2001) mendefinisikan tembawang sebagai kebun (dapat berupa hutan sekunder) yang lokasinya berdekatan dengan tempat tinggal warga setempat. Tembawang biasanya diwariskan secara turun temurun dan umurnya dapat mencapai ratusan tahun. Keberadaan tembawang memiliki fungsi utama dalam memenuhi kebutuhan hidup seharihari masyarakat setempat. Dari tembawang dapat diperoleh berbagai macam buah yang dapat dimakan, kayu untuk membuat rumah, sayur dan jamur untuk dimakan.Selain itu keberadaan tembawang dinilai dapat meningkatkan perekonomian masyarakat setempat melalui penjualan hasil bumi ke masyarakat luar suku setempat.

\section{METODE PENELITIAN}

Penelitian ini dilaksanakan padabulan November sampai dengan Desember 2019 di Desa Suka Jaya Kecamatan Tempunak Kabupaten Sintang, Kalimantan Barat yaitu di areal tembawang yang merupakan tembawang adat atau tembawang bersama masyarakat desa tersebut. Pengumpulan data dilakukan melalui wawancara dan eksplorasi lapangan. Wawancara dilakukan untuk mengumpulkan informasi mengenai jenis-jenis tumbuhan lokal baik dari kelompok tumbuhan penghasil buah, tumbuhan obat maupun tumbuhan hias. Informasi tersebut didapatkan dari masyarakat yang sehari-hari memanfaatkan tumbuhan yang ada di tembawang. Selain dengan wawancara, data jenis tumbuhan lokal juga didapatkan dengan eksplorasi lapangan secara langsung untuk mendapatkan data jenis (nama 
Desa Suka Jaya Kabupaten Sintang

lokal, nama ilmiah), famili dan habitus tumbuhan yang ada di tembawang.

Analisis data dilakukan secara deskriptif kualitatif, untuk mendeskripsikan secara detail informasi mengenai jenis tumbuhan lokal yang ditemukan, kelompok tumbuhan (tumbuhan buah, tumbuhan obat, dan tumbuhan hias).

\section{HASIL DAN PEMBAHASAN}

Tembawang Desa Suka Jaya memiliki luas 5 hektar dan merupakan tembawang bersama atau tembawang adat yang dikelola secara bersama-sama dimana kepala desa berperan sebagai pemimpin dalam pengelolaaan tembawang tersebut. Masyarakat Desa Suka Jaya biasa memanfaatkan tembawang untuk memenuhi kebutuhan pangan seharihari. Tembawang ini didominasi oleh tumbuhan atau pohon penghasil buah yang dapat dikonsumsi (edible fruit). Jenis tumbuhan lokal yang ditemukan di Tembawang Desa Suka Jaya dapat dilihat pada Tabel 1 di bawah ini :

Tabel 1. Jenis Tunbuhan Lokal di Areal Tembawang Desa Suka Jaya

\begin{tabular}{|c|c|c|c|c|c|}
\hline No. & Famili & Nama Ilmiah & Nama Lokal & Habitus & $\begin{array}{l}\text { Kelompok } \\
\text { Tumbuhan } \\
\end{array}$ \\
\hline 1 & Anacardiaceae & Mangifera pajang & Mawang & Pohon & \multirow{7}{*}{ Buah } \\
\hline 2 & Apocynaceae & Willughbeia angustifolia & Kubal & Pohon & \\
\hline 3 & Clusiaceae & Garcinia parfiflora & Kandis & Pohon & \\
\hline 4 & Moraceae & Artocarpus lanceifoliur & Ledang & Pohon & \\
\hline 5 & Moraceae & Artocarpus anisophyllus & Mentawak & Pohon & \\
\hline 6 & Phyllanthaceae & Baccaurea angulata & Benit & Pohon & \\
\hline 7 & Phyllanthaceae & Bacaurea macrocarpa & Mak & Pohon & \\
\hline 8 & Myrtaceae & Syzygium polyanthum & Salam & Perdu & \multirow{2}{*}{ Obat } \\
\hline 9 & Verbenaceae & Premna serratofilia & Bebuas & Perdu & \\
\hline 10 & Nepenthaceae & Nepenthes ampularia & Entuyut & Perdu & \multirow{3}{*}{ Hias } \\
\hline 11 & Orchidaceae & Dendrobium crumenatum & Anggrek Puth & Epifit & \\
\hline 12 & Polupodiaceae & Platycerium coronarium & Rajang & Epifit & \\
\hline
\end{tabular}

Dari Tabel 1 diatas, diketahui bahwa terdapat 12 jenis tumbuhan lokal yang tergolong ke dalam 10 famili, dimana habitus dari tumbuhan lokal tersebut didominasi oleh pohon yang merupakan kelompok tumbuhan buah. Tumbuhan penghasil buah merupakan salah satu 
potensi sumberdaya tumbuhan yang

penting bagi masyarakat Desa Suka Jaya karena memiliki banyak manfaat, seperti dapat dikonsumsi langsung, bahan tambahan masakan dan dapat dijual sebagai tambahan penghasilan.

Tembawang merupakan bentuk kearifan lokal masyarakat dari Suku Dayak di Kalimantan Barat, yang terbentuk dari areal bekas ladang berpindah, dimana setelah tanaman pertanian dipanen, maka peladang menanam areal tersebut dengan tumbuhan yang dianggap multiguna seperti jenis tumbuhan buah. Hal ini yang menyebabkan areal Tembawang Desa Suka Jaya di dominasi kelompok tumbuhan buah. Tembawang merupakan salah satu bentuk agroforestri yang juga dikenal dengan istilah kebun hutan (forest garden). Tembawang termasuk ke dalam agroforestri kompleks, dengan penciri utama adalah kenampakan fisik dan dinamika didalamnya yang mirip dengan ekosistem hutan alam (De Foresta et al, 2000).

\section{PENUTUP}

Dari hasil penelitian dapat diambil kesimpulan sebagai berikut :

1. Terdapat 12 jenis tumbuhan lokal dari 10 famili yang terdapat di areal Tembawang Desa Suka Jaya, yaitu Mangifera pajang, Willughbeia angustifolia, Garcinia parfiflora, Artocarpus lanceifoliur, Artocarpus anisophyllus, Baccaurea angulata, Bacaurea macrocarpa, Syzygium polyanthum, Premna serratofilia, Nepenthes ampularia, Dendrobium crumenatum dan Platycerium coronarium.

2. Tumbuhan lokal yang ditemukan terdiri dari kelompok tumbuhan penghasil buah sebanyak 7 jenis, tumbuhan obat sebanyak 3 jenis dan tumbuhan hias sebanyak 2 jenis.

\section{DAFTAR PUSTAKA}

De Foresta, H., Kusworo, A., Michon, G., \& Djatmiko, W. A. (2000). Ketika Kebun Berupa Hutan: Agroforest Khas Indonesia Sebuah Sumbangan Masyarakat. ICRAF, Bogor.

Hutagaol, R. R. (2017). Diversitas Tumbuhan Buah Lokal 
Potensi Tumbuhan Lokal Di Areal Tembawang Desa Suka Jaya Kabupaten Sintang

Pada Areal Tembawang Desa Engkersik Kabupaten Sekadau. Publikasi

Informasi Pertanian, 13(25).

Putra, M. U., Rujehan, R., Sardjono, M. A., Matius, P., \& Ahyauddin, A. (2020). Potensi Agroforestri Di Desa Mara Satu Kabupaten Bulungan Provinsi Kalimantan Utara. Agrifor, 19(1), 5970.
Wibowo, 2012. Pendidikan Berbasis Keunggulan Lokal. Yogyakarta : Diva Press

Widianto, Kurniatun Hairiah, Didik Suharjito dan Mustofa Agung Sardjono. (2003). Fungsi dan Peran Agroforestri. World Agroforestry Centre (ICRAF), Bogor. 


\title{
Pengaruh NPK Mahkota Origin Terhadap Pertumbuhan Dan Hasil Bawang Daun (Allium fistulosum L.)
}

\author{
Nurhadiah dan Siti Nuraini \\ Fakultas Pertanian Universitas Kapuas Sintang \\ Email:dnurhadiah@gmail.com
}

\begin{abstract}
Abstrak: Hasil panen bawang daun di Kalimantan Barat masih rendah, oleh karenanya perlu ditingkatkan. Salah satu kendala dalam meningkatkan pertumbuhan dan hasil bawang daun di Kalimantan Barat adalah tanahnya yang didominsi oleh tanah PMK. Tanah PMK merupakan jenis tanah yang miskin unsur hara terutama $\mathrm{N}, \mathrm{P}$, dan $\mathrm{K}$, oleh karenanya perlu penambahan hara $\mathrm{N}, \mathrm{P}$, dan $\mathrm{K}$, antara lain dengan pemberian NPK Mahkota Origin. Penelitian ini bertujuan untuk mengetahui pengaruh NPK Mahkota Origin terhadap pertumbuhan dan hasil bawang daun pada tanah PMK dan untuk mendapatkan dosis NPK Mahkota Origin yang dapat menghasilkan pertumbuhan serta hasil bawang daun tertinggi pada tanah PMK. Penelitian ini dilakukan lapangan, menggunakan metode Rancangan Acak Kelompok (RAK) yang terdiri atas 5 taraf perlakuan, masingmasing perlakuan diulang 5 kali. Kelima taraf perlakuan tersebut adalah: $\mathrm{n}_{0}=$ Tanpa NPK Mahkota Origin; $\mathrm{n}_{1}=$ Mahkota Origin 25 g per $\mathrm{m}^{2} ; \mathrm{n}_{2}=$ Mahkota Origin 50 g per $\mathrm{m}^{2} ; \mathrm{n}_{3}=$ Mahkota Origin 75 g per $\mathrm{m}^{2} ; \mathrm{n}_{4}=$ Mahkota Origin $100 \mathrm{~g}$ per $\mathrm{m}^{2}$. Tanaman contoh dalam penelitian ini sebanyak 75 tanaman. $\mathrm{P}$ Data dianalisis dengan menggunakan analisis sidik ragam untuk mengetahui pengaruh perlakuan yang diberikan, kemudian dilanjutkan dengan uji BNJ untuk mengetahui taraf perlakuan yang memberikan pengaruh tertinggi dari peubah yang diamati. Hasil penelitian menunjukkan bahwa NPK Mahkota Origin berpengaruh terhadap pertumbuhan dan hasil bawang daun, yang ditunjukkan oleh peubah tinggi tanaman, jumlah daun per rumpun, dan berat tanaman per rumpun. Pertumbuhan dan hasil tertinggi akibat pemberian NPK Mahkota Origin dicapai pada dosis $75 \mathrm{~g}$ per $\mathrm{m}^{2}$, dengan rerata tinggi tanaman $(47,533 \mathrm{~cm})$, rerata jumlah daun per rumpun $(27,667$ helai) dan rerata berat tanaman per rumpun $(0,317 \mathrm{~kg})$.
\end{abstract}

Kata Kunci: NPK Mahkota Origin, Pertumbuhan, Hasil, Bawang Daun

\section{PENDAHULUAN}

Bawang daun (Allium

fistulosum L.) merupakan salah satu jenis tanaman yang cukup dikenal dan berguna bagi masyarakat Kalimantan Barat. Sunaryono (2015:4) menjelaskan bahwa kegunaan bawang daun antara lain sebagai bahan pembuat obat luka bakar dan sebagai penyedap masakan. Sugeng (2013:1-2) menjelaskan bahwa selain rasanya yang enak, bawang daun juga banyak mengandung gizi. Wibowo 
(2015:13) memaparkan bahwa

kandungan gizi dari bawang daun per $100 \mathrm{~g}$ bahan segar adalah: protein $(1,5 \%)$, karbohidrat $(9,2 \%)$, lemak $(0,03 \%)$, beta karoten (50 IU), riboflavin $(0,04 \mathrm{mg}$ per $100 \mathrm{~g})$, thiamin (30 mg per $100 \mathrm{~g}$ ), niasin (20 mg per $100 \mathrm{~g}$ ), dan kalium sebanyak $334 \mathrm{mg}$.

Berkaitan dengan kegunaan dan kandungan gizi pada bawang daun, hasil tanaman ini per satuan luas di Kalimantan Barat masih rendah dibandingkan dengan potensi hasilnya. Rerata hasil bawang daun di Kalimantan Barat adalah 3,54 ton per ha (Badan Pusat Statistik Kalimantan Barat, 2017:200). Sementara rerata potensi hasilnya 18,00 ton per ha (Wibowo, 2015:64). Upaya peningkatan hasil bawang daun di Kalimantan Barat memiliki kendala, mengingat tanah yang banyak tersedia adalah tanah Podsolik Merah Kuning (PMK). Hakim, dkk. (1996:340) menjelaskan bahwa keterbatasan pada tanah PMK antara lain miskin hara, termasuk $\mathrm{N}$, P, dan K. BPS Kalimantan Barat (2017:5) memaparkan bahwa luas tanah PMK di Kalimantan Barat adalah 9,4 juta ha $(63,81 \%)$ dari total luas wilayah Kalimantan Barat. Luasnya tanah PMK ini memberi peluang untuk pengembangan dan peningkatan hasil tanaman bawang daun.

Untuk pengembangan bawang daun pada tanah PMK perlu dicari solusinya, salah satunya yaitu dengan pemberian pupuk $\mathrm{N}, \mathrm{P}$ dan K. Rauf et al., (2000) menjelaskan bahwa hara $\mathrm{N}, \mathrm{P}$, dan $\mathrm{K}$ merupakan hara esensial bagi tanaman dan sekaligus menjadi faktor pembatas bagi pertumbuhan tanaman. Peningkatan dosis pemupukan $\mathrm{N}$ di dalam tanah secara langsung dapat meningkatkan kadar protein $(\mathrm{N})$ dan produksi tanaman jagung, tetapi pemenuhan unsur $\mathrm{N}$ saja tanpa $\mathrm{P}$ dan $\mathrm{K}$ akan menyebabkan tanaman mudah rebah, peka terhadap serangan hama penyakit dan menurunnya kualitas produksi. Selanjutnya Goenadi, (2006) menyatakan bahwa pemupukan $\mathrm{P}$ yang dilakukan terus menerus tanpa menghiraukan kadar $\mathrm{P}$ tanah yang sudah jenuh telah pula mengakibatkan menurunnya tanggap tanaman terhadap pemupukan $\mathrm{P}$ dan Winarso (2005) menambahkan bahwa tanaman yang dipupuk $\mathrm{P}$ dan 
$\mathrm{K}$ saja tanpa disertai $\mathrm{N}$, hanya mampu menaikkan produksi yang lebih rendah.

Kekurangan hara pada tanah PMK dapat diatasi dengan pemberian pupuk NPK, antara lain adalah NPK Mahkota Origin. Menurut PT. Wilmar Chemical Indonesia, (2017:1) NPK Mahkota Origin memiliki komposisi hara sama $(\mathrm{N}: \mathrm{P}: \mathrm{K}=16: 16: 16)$ dan harganya relatif lebih murah. Selain harganya yang lebih murah, NPK Mahkota Origin dapat meningkatkan pertumbuhan dan hasil tanaman yang tidak berbeda nyata dengan NPK jenis lainnya. Adapun tujuan penelitian ini yaitu untuk mengetahui pengaruh NPK Mahkota Origin terhadap pertumbuhan dan hasil bawang daun pada tanah PMK; serta untuk mendapatkan dosis NPK Mahkota Origin yang tepat dalam memberikan pertumbuhan dan hasil bawang daun tertinggi pada tanah PMK .

\section{METODOLOGI PENELITIAN}

Penelitian ini dilakukan lapangan, menggunakan metode Rancangan Acak Kelompok (RAK) yang terdiri atas 5 taraf perlakuan, masing-masing perlakuan diulang 5 kali. Kelima taraf perlakuan tersebut adalah: $\mathrm{n}_{0}=$ Tanpa NPK Mahkota Origin; $\mathrm{n}_{1}=$ Mahkota Origin 25 g per $\mathrm{m}^{2} ; \mathrm{n}_{2}=$ Mahkota Origin $50 \mathrm{~g}$ per $\mathrm{m}^{2} ; \mathrm{n}_{3}=$ Mahkota Origin $75 \mathrm{~g}$ per $\mathrm{m}^{2} ; \mathrm{n}_{4}=$ Mahkota Origin $100 \mathrm{~g}$ per $\mathrm{m}^{2}$. Tanaman contoh dalam penelitian ini adalah 3 tanaman yang diambil dari 9 tanaman dalam setiap petak percobaan. Jumlah seluruh satuan pengamatan adalah 5 perlakuan $\times 5$ ulangan $\times 3$ tanaman $=$ 75 tanaman, diambil dari 225 tanaman. Alat-alat yang digunakan dalam penelitian ini yaitu: sabit, cangkul, kantong plastik berwarna hitam, gergaji, triplek, gunting, timbangan, ember, gembor, mini sprayer, meteran, kamera digital, alat tulis menulis, komputer. Bahan bahan yang digunakan yaitu: bibit bawang daun, tanah PMK, NPK Mahkota Origin. Peubah yang diamati adalah tinggi tanaman, jumlah daun per rumpun dan berat tanaman per rumpun. Data dianalisis dengan menggunakan analisis sidik ragam untuk mengetahui pengaruh perlakuan yang diberikan, kemudian dilanjutkan dengan uji BNJ untuk mengetahui taraf perlakuan yang 
memberikan pengaruh tertinggi dari peubah yang diamati. Penelitian dilakukan di desa Balai Agung kecamatan Sungai Tebelian, kabupaten Sintang.

\section{HASIL PENELITIAN}

Tinggi Tanaman

Tanaman contoh yang berjumlah 3 tanaman, masing-masing diukur tingginya dari pangkal batang hingga ujung daun tertinggi pada saat panen. Data rerata tinggi tanaman dianalisis yang hasilnya disajikan pada Tabel 1.

Tabel 1. Hasil Analisis Sidik Ragam Pengaruh NPK Mahkota Origin terhadap Tinggi Tanaman Bawang Daun

\begin{tabular}{lccccrc}
\hline \multirow{1}{c}{ SK } & \multirow{2}{*}{ DB } & \multirow{2}{*}{ JK } & \multirow{2}{*}{ KT } & \multirow{2}{*}{ F hit } & \multicolumn{2}{c}{ F Tabel } \\
\cline { 6 - 8 } & & & & & $\mathbf{0 . 0 5}$ & F.0.01 \\
\hline Kelompok & 4 & 118.482 & 29.621 & $5.446^{* *}$ & 3.01 & 4.77 \\
Perlakuan & 4 & 957.404 & 239.351 & $44.010^{* *}$ & 3.01 & 4.77 \\
Galat & 16 & 87.018 & 5.439 & & & \\
\hline Total & $\mathbf{2 4}$ & $\mathbf{1 . 1 6 2 . 9 0 4}$ & \multicolumn{3}{c}{ KK $=\mathbf{5 , 6 0 2} \%$} \\
\hline
\end{tabular}

Sumber: Hasil analisis data, 2020

Keterangan: $* *=$ Berpengaruh pada selang kepercayaan $99 \%$

Hasil analisis sidik ragam antar taraf perlakuan NPK Mahkota (Tabel 1) menunjukkan bahwa Origin dilanjutkan dengan uji BNJ perlakuan sangat berpengaruh pada taraf nyata $5 \%$ dan $1 \%$ yang terhadap tinggi tanaman. Untuk disajikan pada Tabel 2. mengetahui perbedaan pengaruh

Tabel 2. Hasil Uji BNJ Pengaruh NPK Mahkota Origin terhadap Tinggi Tanaman bawang daun $(\mathrm{cm})$

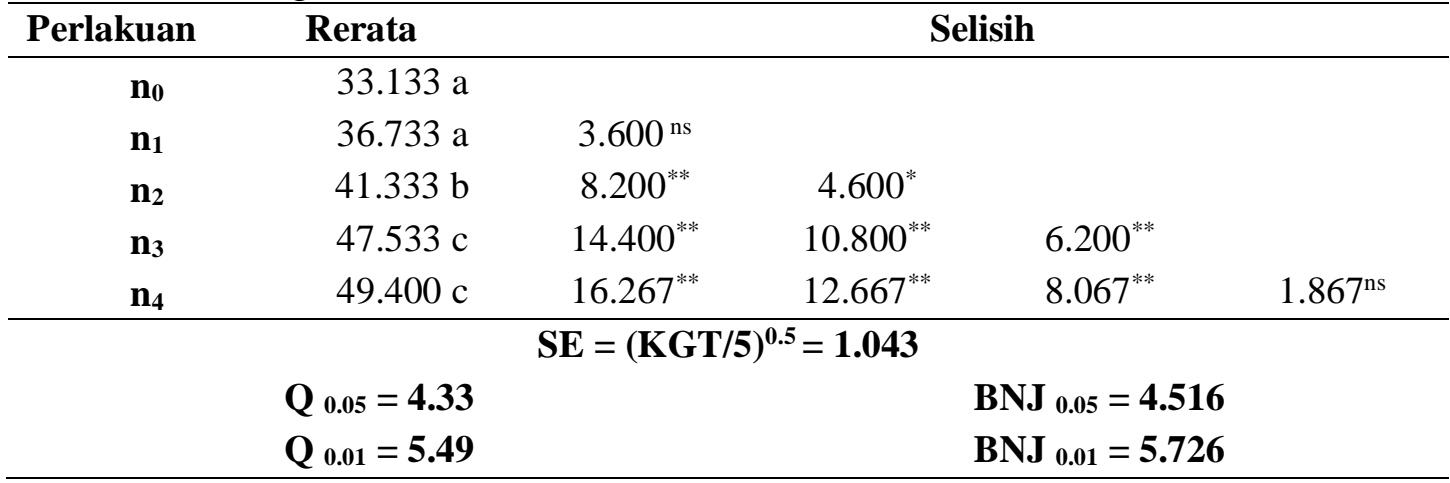

Sumber: Hasil analisis data, 2020

Keterangan: Nilai rerata yang diikuti huruf yang sama tidak berbeda nyata 
Hasil uji BNJ menunjukkan bahwa pemberian NPK Mahkota Origin pada dosis $75 \mathrm{~g}$ per $\mathrm{m}^{2} \quad\left(\mathrm{n}_{3}\right)$ menghasilkan rerata tinggi tanaman yang tidak berbeda pada selang kepercayaan $95 \%$ dengan dosis $100 \mathrm{~g}$ per $\mathrm{m}^{2}\left(\mathrm{n}_{4}\right)$, lebih tinggi dibanding dosis $50 \mathrm{~g}$ per $\mathrm{m}^{2}\left(\mathrm{n}_{2}\right), 25 \mathrm{~g}$ per $\mathrm{m}^{2}$ $\left(\mathrm{n}_{1}\right)$, dan tanpa pemberian NPK Mahkota Origin $\left(\mathrm{n}_{0}\right)$. Berdasarkan hasil uji BNJ tersebut dinyatakan bahwa perlakuan yang memberikan rerata tinggi tanaman tertinggi adalah $\mathrm{n}_{3}$, pada perlakuan tersebut menghasilkan rerata tinggi tanaman $47,533 \mathrm{~cm}$.

Jumlah Daun

Tanaman contoh yang berjumlah 3 tanaman, masing-masing dihitung jumlah daunnya pada saat panen. Data rerata jumlah daun dianalisis yang hasilnya disajikan pada Tabel 3.

Tabel 3. Hasil Analisis Sidik Ragam Pengaruh NPK Mahkota Origin terhadap Jumlah Daun

\begin{tabular}{lcrrrrr}
\hline \multicolumn{1}{c}{ SK } & DB & \multicolumn{1}{c}{ JK } & \multicolumn{2}{c}{ KT } & F hit & \multicolumn{2}{c}{ F Tabel } \\
\cline { 6 - 7 } & & & & & $\mathbf{0 . 0 5}$ & F.0.01 \\
\hline Kelompok & 4 & 57.573 & 14.393 & $3.303^{*}$ & 3.01 & 4.77 \\
Perlakuan & 4 & 730.418 & 182.604 & $41.908^{* *}$ & 3.01 & 4.77 \\
Galat & 16 & 69.716 & 4.357 & & & \\
\hline Total & $\mathbf{2 4}$ & $\mathbf{8 5 7 . 7 0 7}$ & & KK $=\mathbf{9 , 0 9 7 \%}$ & \\
\hline
\end{tabular}

Sumber: Hasil analisis data, 2020

Keterangan: $\quad *=$ Berpengaruh pada selang kepercayaan $95 \%$ $* *=$ Berpengaruh pada selang kpercayaan $99 \%$

Hasil analisis sidik ragam

(Tabel 3) menunjukkan bahwa perlakuan sangat berpengaruh terhadap jumlah daun. Untuk mengetahui perbedaan pengaruh antar taraf perlakuan NPK Mahkota Origin dilanjutkan dengan uji BNJ pada taraf nyata $5 \%$ dan $1 \%$ yang disajikan pada Tabel 4. 
Tabel 4. Hasil Uji BNJ Pengaruh NPK Mahkota Origin terhadap Jumlah Daun (helai)

\begin{tabular}{|c|c|c|c|c|c|}
\hline Perlakuan & Rerata & \multicolumn{4}{|c|}{ Selisih } \\
\hline no & $15.267 \mathrm{a}$ & & & & \\
\hline $\mathbf{n}_{1}$ & $18.733 a$ & $3.467^{\mathrm{ns}}$ & & & \\
\hline $\mathbf{n}_{2}$ & $23.267 b$ & $8.000^{* *}$ & $4.533^{* *}$ & & \\
\hline $\mathbf{n}_{3}$ & $27.667 \mathrm{c}$ & $12.400^{* *}$ & $8.933^{* *}$ & $4.400^{*}$ & \\
\hline $\mathbf{n}_{4}$ & $29.800 \mathrm{c}$ & $14.533^{* *}$ & $11.067^{* *}$ & $6.533^{* *}$ & $2.133^{\mathrm{ns}}$ \\
\hline \multicolumn{6}{|c|}{$\mathrm{SE}=(\mathrm{KGT} / 5)^{0.5}=0.934$} \\
\hline \multirow{2}{*}{\multicolumn{2}{|c|}{$\begin{array}{l}Q_{0.05}=4.33 \\
Q_{0.01}=5.49\end{array}$}} & & \multicolumn{3}{|c|}{ BNJ $0.05=4.042$} \\
\hline & & & \multicolumn{3}{|c|}{ BNJ $0.01=5.125$} \\
\hline
\end{tabular}

Sumber: Hasil analisis data, 2020

Keterangan: Nilai rerata yang diikuti huruf yang sama tidak berbeda nyata

Hasil uji BNJ menunjukkan bahwa pemberian NPK Mahkota Origin pada dosis $75 \mathrm{~g}$ per $\mathrm{m}^{2}\left(\mathrm{n}_{3}\right)$ menghasilkan rerata jumlah daun per rumpun yang tidak berbeda pada selang kepercayaan $95 \%$ dengan dosis $100 \mathrm{~g}$ per $\mathrm{m}^{2}\left(\mathrm{n}_{4}\right)$, lebih banyak dibanding dosis $50 \mathrm{~g}$ per $\mathrm{m}^{2}\left(\mathrm{n}_{2}\right), 25$ $\mathrm{g}$ per $\mathrm{m}^{2}\left(\mathrm{n}_{1}\right)$ dan tanpa pemberian NPK Mahkota Origin $\left(\mathrm{n}_{0}\right)$. Berdasarkan hasil uji BNJ tersebut dinyatakan bahwa perlakuan yang memberikan rerata junmlah daun per rumpun terbanyak adalah $\mathrm{n}_{3}$, dimana rerata jumlah daun per rumpun adalah 27,667 helai.

Berat Tanaman

Tanaman contoh yang berjumlah 3 tanaman, masing-masing ditimbang beratnya satu per satu pada saat panen. Data $r$ erata berat tanaman dianalisis yang hasilnya disajikan pada Tabel 5.

Tabel 5. Hasil Analisis Sidik Ragam Pengaruh NPK Mahkota Origin terhadap Berat Tanaman Bawang Daun

\begin{tabular}{|c|c|c|c|c|c|c|}
\hline \multirow{2}{*}{ SK } & \multirow{2}{*}{ DB } & \multirow{2}{*}{ JK } & \multirow{2}{*}{ KT } & \multirow{2}{*}{ F hit } & \multicolumn{2}{|c|}{ F Tabel } \\
\hline & & & & & 0.05 & 0.01 \\
\hline$\overline{\text { Kelompok }}$ & 4 & 0.009 & 0.002 & $3.792^{*}$ & 3.01 & 4.77 \\
\hline Perlakuan & 4 & 0.044 & 0.011 & $18.014^{* *}$ & 3.01 & 4.77 \\
\hline Galat & 16 & 0.010 & 0.001 & & & \\
\hline Total & 24 & 0.063 & & $\mathbf{K K}=\mathbf{9}$ & & \\
\hline
\end{tabular}

Sumber: Hasil analisis data, 2020

Keterangan: $\quad *=$ Berpengaruh pada selang kepercayaan $95 \%$ $* *=$ Berpengaruh pada selang kepercayaan $99 \%$ 


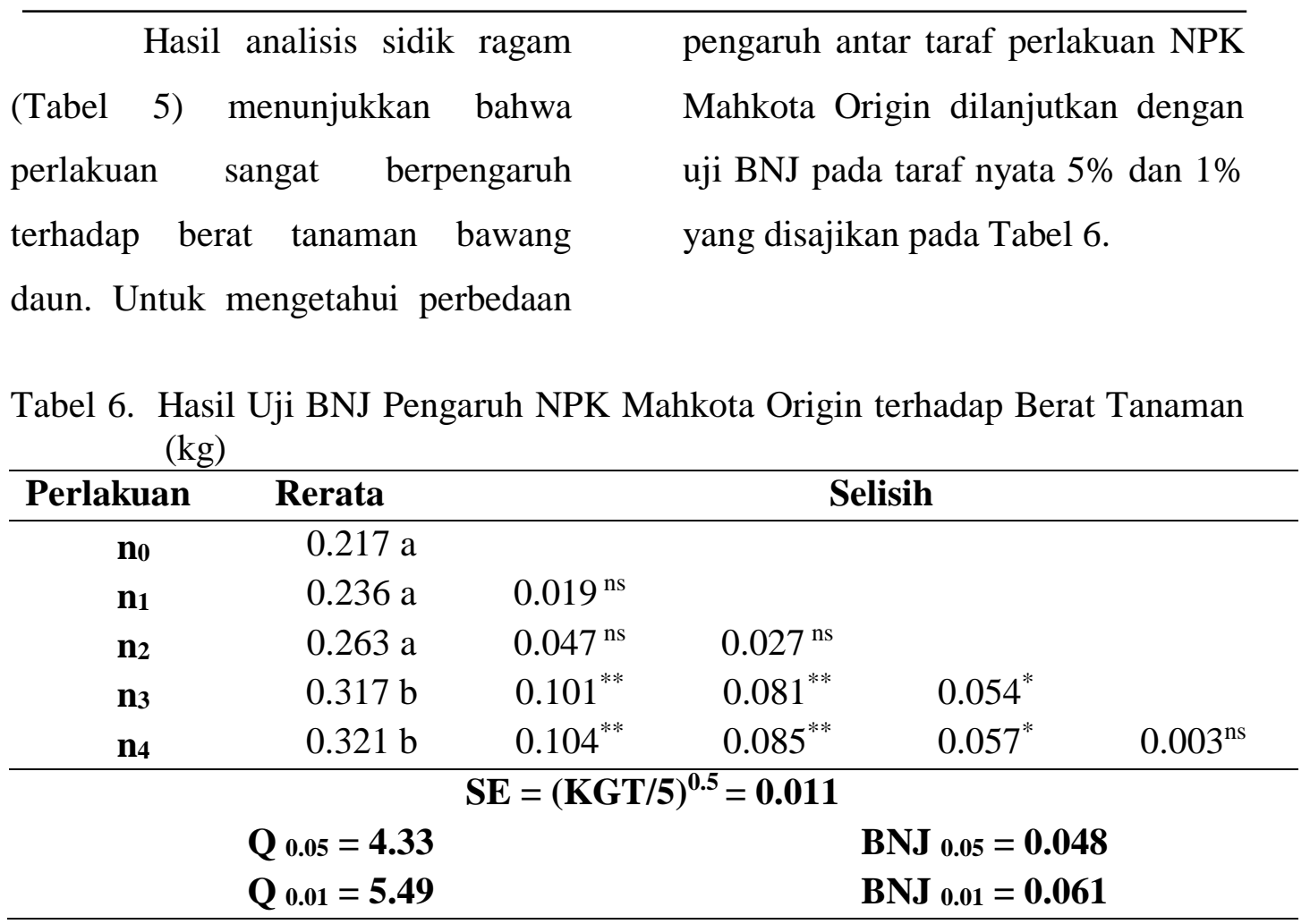

Sumber: Hasil analisis data, 2020

Keterangan: Nilai rerata yang diikuti huruf yang sama tidak berbeda nyata

Hasil uji BNJ menunjukkan

bahwa pemberian NPK Mahkota

Origin pada dosis 75 g per $\mathrm{m}^{2}\left(\mathrm{n}_{3}\right)$

menghasilkan rerata berat tanaman

per rumpun yang tidak berbeda pada

selang kepercayaan $95 \%$ dengan

dosis $100 \mathrm{~g}_{\text {per }} \mathrm{m}^{2}\left(\mathrm{n}_{4}\right)$, lebih berat

dibanding dosis $50 \mathrm{~g}$ per $\mathrm{m}^{2}\left(\mathrm{n}_{2}\right), 25$

g per $\mathrm{m}^{2}\left(\mathrm{n}_{1}\right)$, dan tanpa pemberian

NPK Mahkota Origin $\left(\mathrm{n}_{0}\right)$.

Berdasarkan hasil uji BNJ tersebut

dinyatakan bahwa perlakuan yang

memberikan rerata berat tanaman per

rumpun terberat adalah $\mathrm{n}_{3}$,

menghasilkan rerata berat tanaman

per rumpun $0,317 \mathrm{~kg}$.

\section{PEMBAHASAN}

Hasil penelitian menunjukan bahwa NPK Mahkota Origin dapat meningkatkan tinggi tanaman, jumlah daun, dan berat tanaman per rumpun. Hasil penelitian ini menunjukkan bahwa NPK Mahkota Origin dapat meningkatkan pertumbuhan dan hasil bawang daun. Ketersediaan N, P dan K dalam tanah menjadi meningkat karena pemberian NPK Mahkota Origin. Nyakpa, dkk. menjelaskan bahwa unsur $\mathrm{N}, \mathrm{P}$, dan $\mathrm{K}$, merupakan unsur esensial bagi tanaman. Menurut Dwidjoseputro 
(2010:29) unsur N, P, dan K peranannya amat penting dalam metabolisme tanaman, dimana $\mathrm{N}$ merupakan unsur penyusun senyawa esensial seperti asam amino (Sutejo, 2014:26), selain itu Dwidjoseputro (2010:29) menjelaskan bahwa $\mathrm{N}$ merupakan unsur yang sangat diperlukan oleh tanaman untuk mendukung pertumbuhan dan produksinya. Kekurangan N mengakibatkan daun tanaman menguning dan jika dibiarkan akibatnya tanaman akan mati.

Selain unsur N, Lakitan (2001:67) menjelaskan bahwa P sangat diperlukan dalam pertumbuhan akar dan perkembangan biji tanaman. Gardner et al., (2011:154-155) menjelaskan bahwa $\mathrm{P}$ merupakan bagian yang esensial dari berbagai gula Fosfat yang amat berperan dalam reksi metabolisme tumbuhan. Selanjutnya menurut Gardner et al., (2011:154155) $\mathrm{P}$ merupakan komponen struktural dari senyawa penting, seperti ADP, ATP, NAD, NADPH, DNA, dan RNA. ADP, ATP, NAD, dan NADPH merupakan molekul pentransfer energi, DNA dan RNA merupakan senyawa sistem informasi genetik. Lebih lanjut dijelaskan bahwa $\mathrm{P}$ juga merupakan bahan penyusun fosfolipid, senyawa ini memegang peranan penting dalam integritas membran sel. Kekurangan $\mathrm{P}$ menyebabkan pembentukan warna ungu yang berlebihan di lembaran daun, akibatnya pertumbuhan tanaman menjadi terhambat. Lingga dan Marsono (2013:36) menjelaskan bahwa kekurangan $\mathrm{P}$ menyebabkan pembentukan warna ungu yang berlebihan di lembaran daun, akibatnya pertumbuhan tanaman menjadi terhambat.

Berbeda dengan unsur $\mathrm{N}$ dan $\mathrm{P}$ yang berperan dalam menyusun struktur tubuh tanaman, unsur K menurut Nyakpa, dkk., (1998:97-98) membantu memelihara potensial osmotik sel dan menjaga kehilangan air dari dalam sel tumbuhan. Berperan sebagai aktivator enzim (Dwijoseputro, 1999:30), memacu pembentukan protein dan karbohidrat serta memperkuat pertumbuhan tanaman (Setyamidjaya, 2013:36).

Hasil penelitian menunjukkan bahwa rerata tinggi tanaman tertinggi $(47,533 \mathrm{~cm})$, rerata jumlah daun per rumpun terbanyak (27,667 helai) dan rerata berat tanaman per rumpun 
terberat $(0,317 \mathrm{~kg})$ dicapai pada pemberian NPK Mahkota Origin 75 g per $\mathrm{m}^{2}\left(\mathrm{n}_{3}\right)$. Dosis NPK Mahkota Origin yang memberikaan pertumbuhan dan hasil tertinggi bukan dicapai pada dosis tertinggi (100 g per $\left.\mathrm{m}^{2}\right)$ melainkan dicapai pada taraf dosis di bawahnya (75 $\mathrm{g}$ per $\mathrm{m}^{2}$ ). Dosis NPK Mahkota Origin $75 \mathrm{~g}$ per $\mathrm{m}^{2}$ diduga merupakan penambahan hara ke dalam tanah yang menyebabkan status hara dalam tubuh tanaman telah mencapai kondisi peralihan (kondisi yang kurang unsur hara beralih menjadi tersedia dan cukup) untuk pertumbuhan dan hasil tanaman. Pemberian NPK Mahkota Origin di atas dosis $75 \mathrm{~g}$ per $\mathrm{m}^{2}$ tidak lagi diikuti oleh peningkatan pertumbuhan dan hasil tanaman. Dugaan tersebut sejalan dengan penjelasan Gardner et al., (2011:137138) bahwa status nutrisi dalam jaringan tanaman dapat dideskripsikan ke dalam zona defisiensi, zona peralihan, zona kecukupan, dan zona beracun. Menurut Susantidiana (2011) salah satu faktor yang menunjang pertumbuhan dan produksi tanaman adalah unsur hara. Unsur hara harus tersedia dalam jumlah yang cukup sehingga pertumbuhan dan produksi akan optimal.

\section{KESIMPULAN DAN SARAN}

\section{Kesimpulan}

Berdasarkan hasil penelitian yang sudah dilakukan, dapat disimpilkan bahwa NPK Mahkota Origin berpengaruh terhadap pertumbuhan dan hasil bawang daun, yang ditunjukkan oleh peubah tinggi tanaman, jumlah daun per rumpun, dan berat tanaman per rumpun. Pertumbuhan dan hasil tertinggi akibat pemberian NPK Mahkota Origin dicapai pada dosis $75 \mathrm{~g}$ per $\mathrm{m}^{2}$, dengan rerata tinggi tanaman $(47,533 \mathrm{~cm})$, rerata jumlah daun per rumpun $(27,667$ helai) dan rerata berat tanaman per rumpun $(0,317$ $\mathrm{kg})$.

\section{Saran}

Bagi para petani yang akan membudidayakan bawang daun dengan Mahkota Origin disarankan untuk menggunakan dosis $75 \mathrm{~g}$ per $\mathrm{m}^{2}$. 


\section{DAFTAR PUSTAKA}

BPS Kalimantan Barat 2017.

Kalimantan Barat Dalam

Angka. Pontianak. Badan

Pusat Statistik Kalimantan

Barat.

Dwidjoseputro, D. 2010. Pengantar

Fisiologi

Tumbuhan.

Jakarta. Gramedia.

Gardner, F.P., Pearce, R.B. dan Mitchell, R.L. 2011. Diterjemahkan oleh Herawati, S. Fisiologi Tanaman Budidaya. Jakarta. Universitas Indonesia.

Goenadi, D.H. 2006. Teknologi Pupuk dan Pemupukan Berbasis Hayati dari Cawan Petri ke Lahan Petani. Yayasan John Hi-Tech Idetama. Jakarta.

Hakim, N., Nyakpa, M.Y., Lubis, A.M., Sutopo, G.N., Saul, M.R., Diha, M.A., Go Ban Hong, dan Bailey, H.H. 1996. Dasar Dasar Ilmu Tanah. Bandar Lampung. Universitas Lampung.

Lakitan, B. 2001.Fisiologi

Tumbuhan. Rajawai Pressindo. Jakarta

Lingga, P dan Marsomo. 2013. Pupuk dan Petunjuk Penggunaan Pupuk. Jakarta. Penebarswadaya.
Nyakpa, M.Y., Lubis, A.M., Pulung, M.A., Amrah, A.G., Munawar, A., Go Ban Hong, dan Hakim, N. 1998. Kesuburan Tanah, Lampung. Universitas Lampung.

PT Wilmar Senical Indonsia. 2017. "Pengenalam Pupuk NPK Mahkota Origin” . Brosur. Jakarta. PT Wilmar Senical Indonesia.

Rauf A, Shepard BM, Johnson MW. 2000. Leafminers in vegetables, ornamental plants and weeds in Indonesia: Surveys of host crops, species composition and parasitoids. International Journal of Pest Management. 46(4):257-266.

Setyamidjaya, J. 2013. Pupuk dan Petunjuk Penggunaan Pupuk. Jakarta. Penebar Swadaya.

Sugeng, H.R. 2013. Bercocok Tanam Sayuran. Semarang. Aneka Ilmu.

Sunaryono, H. 2015. Bercocok Tanam Bawang Daun. Jakarta. Penebar Swadaya.

Susantidiana. 2011. Peran Media Tanam dan Dosis Pupuk Urea, SP36, $\mathrm{KCl}$ Terhadap Pertumbuhan Tanaman Bawang Daun (Allium fistulosum L.) dalam Polybag. Agronobis. 3(5) 
Pengaruh NPK Mahkota Origin Terhadap Pertumbuhan Dan Hasil Bawang Daun (Allium Fistulosum L.)

:17- 21. ISSN: 1979 - $\quad$ Wibowo,S. 2015. Budidaya $8245 \mathrm{X}$. Bawang. Jakarta. Penebar Swadaya.

Sutejo, M.M. 2014. Pupuk dan

Cara Pemupukan. Jakarta. Rineka Cipta.

Winarso, S. 2005. Kesuburan Tanah: Dasar Kesehatan dan Kualitas Tanah (TNH). Yogyakarta. Penerbit Gaya Media. 